\title{
Potential risk indicators of retained placenta and other diseases in multiparous cows
}

\author{
Y. Qu, ${ }^{*}$ A. N. Fadden, $\nmid$ M. G. Traber, $\downarrow \ddagger$ and G. Bobe ${ }^{*}{ }^{1}$ \\ *Department of Animal and Rangeland Sciences, College of Agriculture, and \\ †School of Biological and Population Health Sciences, Oregon State University, Corvallis 97331-4802 \\ fLinus Pauling Institute, Oregon State University, Corvallis 97331-6512
}

\section{ABSTRACT}

Retained placenta (RP), defined as fetal membranes not being expelled within $24 \mathrm{~h}$ after calving, is a costly disease in multiparous dairy cows that has been linked to immune suppression, infections, elevated lipid mobilization, and depleted status of antioxidants including $\alpha$-tocopherol, and that increases the risk of other diseases (OD) in early lactation. Early detection of cows at increased risk of developing RP, OD, or both in early lactation could improve treatment success and result in improved milk production and reproductive performance. To identify risk indicators of RP, OD, or both, we used a nested case-control design and compared multiparous dairy cows that developed RP (n $=32)$ with cows that remained healthy $(\mathrm{H} ; \mathrm{n}=32)$ or cows that developed OD $(\mathrm{n}=32)$ in early lactation. We compared peripartal body condition score (BCS) as well as serum concentrations of $\alpha$-tocopherol, metabolites [ $\beta$-hydroxybutyrate (BHBA), cholesterol, glucose, nonesterified fatty acids (NEFA), and urea N], haptoglobin, and macrominerals (i.e., calcium, magnesium, and phosphorus) on $\mathrm{d}-21,-14,-7,-3,-1,0,1,3$, $7,14,21,28,35,42$, and 49 postpartum. In addition, average serum concentrations were calculated for each cow for the last 3 wk prepartum, for 3 and 2 wk prepartum combined, for the last week prepartum, and for the morning after calving and compared between groups. The RP cows had lower BCS than the H or OD cows until 2 wk postpartum. During the prepartal periods, $\mathrm{RP}$ and OD cows had lower $\alpha$-tocopherol concentrations (corrected or not for cholesterol concentration) and higher NEFA and BHBA concentrations than $\mathrm{H}$ cows. Thus, lower prepartal BCS could be an early predictor for RP risk, and lower $\alpha$-tocopherol concentrations and higher NEFA and BHBA concentrations could be early predictors for disease.

Received January 18, 2013.

Accepted March 16, 2014.

${ }^{1}$ Corresponding author: gerd.bobe@oregonstate.edu
Key words: $\alpha$-tocopherol, biomarker, dairy cow, disease, retained placenta

\section{INTRODUCTION}

Normal expulsion of fetal membranes occurs within $8 \mathrm{~h}$ after calf delivery. Retained placenta $(\mathbf{R P})$ is defined as failure to expel fetal membranes within $24 \mathrm{~h}$ (Kelton et al., 1998). Retained placenta is an economically important disease that affects approximately $7.8 \%$ (range: 1.3 to $39.2 \%$ ) of US dairy cows (Kelton et al., 1998; USDA, 2009). The average cost of RP, including treatment costs, milk loss, and increased days open, is estimated to be $\$ 285$ per case (Kelton et al., 1998). Additional RP-associated costs that are not included in the cost estimate are increased culling rates and increased incidence of other diseases (OD), as RP is an established risk factor for metritis and ketosis (Curtis et al., 1985; Markusfeld, 1987; Laven and Peters, 1996). The primary risk factors associated with RP are premature births, multiple calves, dystocia, abortion, stillbirths, uterine infections, age of cow, milk fever, antioxidant (e.g., selenium, $\alpha$-tocopherol, and $\beta$-carotene) deficiency, and calving season (reviewed in Laven and Peters, 1996; Drillich, 2011).

Multiple physical, endocrine, and cellular factors are involved in the expulsion of fetal membranes. Several causes for RP have been proposed in recent years: (1) uterine atony ( $<2 \%$ of cases); $(2)$ edema of the chorionic villi as a consequence of physical damage associated with birthing complications, caesarian section, or twisted uterus; (3) cellular dysfunction and necrosis related to uterine infections; (4) incomplete breakdown of extracellular matrix by collagenase and matrix metalloproteinases related to steroid hormone imbalances; (5) decreased innate and humoral immune responses; and (6) oxidative damage associated with insufficient antioxidants (McNaughton and Murray, 2009; Drillich, 2011).

Given the economic losses associated with RP and OD in early lactation (Kelton et al., 1998), early detection of cows at increased risk of developing RP, OD, or 
both could improve treatment success and result in improved milk production and reproductive performance. To date, circulating NEFA concentrations $>300$ to 500 $\mu \mathrm{Eq} / \mathrm{L}$ have been reported as an early indicator of RP in large, multi-herd field trials in the last week prepartum (LeBlanc et al., 2004; Ospina et al., 2010; Chapinal et al., 2011). Elevated NEFA concentrations in the last week prepartum, however, are also a risk indicator for OD in early lactation (Ospina et al., 2010; Moyes et al., 2013). Furthermore, risk indicators detected in the last week precalving leave little time for RP or OD prevention. Using data from a large vitamin E supplementation trial in the Guelph, Canada, area (LeBlanc et al., 2002), LeBlanc et al. (2004) showed that cows that developed RP had, in the last week prepartum, lower serum $\alpha$-tocopherol concentrations than cows that did not develop RP. Although inflammation and macromineral status have been implicated in the development of $\mathrm{RP}$, the association between serum markers of inflammation (e.g., haptoglobin) and macromineral status (i.e., calcium, magnesium, and phosphorus) prepartum and RP has not to our knowledge been reported. The exception is calcium; in large, multi-herd field trials during the last week precalving, calcium concentrations and RP incidence were not associated (Quiroz-Rocha et al., 2009; Chapinal et al., 2011).

We hypothesized that BCS and serum concentrations of markers of antioxidant status ( $\alpha$-tocopherol), lipid transport (cholesterol), energy and nitrogen balance (i.e., BHBA, glucose, NEFA, and urea N), inflammation (haptoglobin), and macromineral status (i.e., calcium, magnesium, and phosphorus) are altered before and after RP as well as OD. The objective of this study was to compare during the peripartal period ( -3 to 7 wk postpartum) BCS and serum concentrations of these various markers between multiparous dairy cows that developed RP, OD (i.e., metritis, mastitis, ketosis, or laminitis), or remained healthy in early lactation.

\section{MATERIALS AND METHODS}

\section{Animals and Study Design}

All procedures involving animals were approved by the Oregon State University Institutional Animal Care and Use committee. The research was conducted on a 1,000-head commercial dairy farm in Oregon's Central Willamette Valley during spring and summer 2010. We only collected blood samples and monitored the health of purebred pregnant Holstein cows that had completed $\geq 1$ lactation, were free of diseases, and had a BCS of $\geq 3.0$ at the start of the study. The cohort consisted of 161 multiparous Holstein cows (upcoming parity 2 to 7). Using a nested case-control design, we identified cows that developed RP ( $\mathrm{n}=32)$, developed OD ( $\mathrm{n}$ $=32$; i.e., metritis, mastitis, ketosis, or laminitis), or remained healthy $(\mathbf{H} ; \mathrm{n}=32)$ during the first $28 \mathrm{~d}$ after calving. Cows were matched based on parity and calving season.

Starting $28 \mathrm{~d}$ before predicted calving date, BCS of cows were scored $1 \times /$ wk by 3 trained, independent evaluators until 4 wk postpartum and then at wk 7 and 14 postpartum (Edmonson et al., 1989). During the last $4 \mathrm{wk}$ before expected calving, cows were housed in a straw-bedded freestall barn and were fed once in the morning (0730 h) a TMR based on corn, corn silage, and alfalfa and triticale hay, which met NRC (2001) guidelines and contained vitamin $\mathrm{E}$ at $167 \mathrm{IU} / \mathrm{kg}$ of DM as all-rac- $\alpha$-tocopheryl acetate (Table 1). After calving, healthy cows stayed the first $2 \mathrm{~d}$ in the hospital pen, and then for 4 wk in the early lactation pen, and then for wk 5 to 17 postpartum based on body size (largest, medium, and smallest based on height and depth of cows) in 3 mid-lactation pens. Cows diagnosed with diseases were moved back to the hospital pen for treatment. Cows were fed around 0800 and $1330 \mathrm{~h}$ a TMR based on corn, corn silage, and alfalfa hay, which met NRC (2001) guidelines and contained vitamin E at 24.5 $\mathrm{IU} / \mathrm{kg}$ of DM as all-rac- $\alpha$-tocopheryl acetate (Table 1).

\section{Animal Health Surveillance and Disease Treatment}

During the study period, cows were monitored daily for abnormal milk, gait, appetite, general appearance, alertness, vaginal discharge, and RP. Uterine discharge and milk SCC were checked $2 \times /$ wk. Urinary ketones and body temperature were checked if a cow appeared not healthy, which included depressed feed intake, lethargy, cold ears, and rapid BCS loss. Diseases were diagnosed and treated based on standard operating procedures developed by the Oregon State University veterinary staff and were consistent with standard of care veterinary practices. Diagnosis and treatment of diseases was done by the herd manager, who was trained and supervised by the Oregon State University veterinarian. The veterinarian visited at least $1 \times /$ wk to supervise diagnosis and treatment of diseases.

Retained placenta was diagnosed as failure to expel fetal membranes within $24 \mathrm{~h}$ after parturition. Cows with $\mathrm{RP}$ remained in the hospital pen and were infused with $57 \mathrm{~g}$ of tetracycline $\mathrm{HCl}$ powder (714 g of tetracycline/ kg; IVX Animal Health Inc., St. Joseph, MO) in 1 L of water every 4 to $8 \mathrm{~d}$ until the placenta was expelled. To prevent infections, cows were injected i.m. for up to $7 \mathrm{~d}$ with penicillin $(40 \mathrm{~mL} / \mathrm{d}$, Penicillin G Procaine; Aspen Veterinary Resources Ltd., Liberty, MO), followed by treatment for up to $7 \mathrm{~d}$ with sulfadimethoxine $(30 \mathrm{~g} / \mathrm{d}$, Sulfasol soluble powder, Med-Pharmex, Pomona, CA). 
Table 1. Feed and nutrient composition of pre- and postpartum diets

\begin{tabular}{|c|c|c|}
\hline \multirow[b]{2}{*}{ Feed composition } & \multicolumn{2}{|c|}{ Percentage of diet DM } \\
\hline & Prepartum & Postpartum \\
\hline \multicolumn{3}{|l|}{ Ingredient } \\
\hline Grass silage & & 2.13 \\
\hline Alfalfa hay ( $20 \% \mathrm{CP}, 36 \% \mathrm{NDF})$ & 13.42 & 19.26 \\
\hline Corn silage & 27.77 & 20.93 \\
\hline Triticale hay ( $9 \%$ CP, $60 \%$ NDF) & 13.69 & - \\
\hline Beet pulp & 3.41 & - \\
\hline Vitamin and mineral premix ${ }^{1}$ & 4.95 & - \\
\hline Vitamin and mineral premix ${ }^{2}$ & - & 2.96 \\
\hline $\mathrm{MgOx}^{3}$ & 0.18 & - \\
\hline Ground corn & 18.15 & - \\
\hline Corn (high moisture ear corn) & - & 20.00 \\
\hline Corn distillers grain (including solubles) & 8.06 & 12.33 \\
\hline Canola meal & 6.69 & 6.40 \\
\hline Wheat distillers grain (including solubles) & - & 5.97 \\
\hline Bakery by-product & - & 6.39 \\
\hline EnerGII Regular ${ }^{4}$ & 1.82 & 1.74 \\
\hline Limestone (ground) & 1.85 & 0.94 \\
\hline Sodium bicarbonate & - & 0.94 \\
\hline \multicolumn{3}{|l|}{ Analyzed nutrient composition } \\
\hline $\mathrm{NE}_{\mathrm{L}}$ (Mcal/kg, DM basis) & 1.63 & 1.70 \\
\hline $\mathrm{CP}$ & 13.0 & 18.7 \\
\hline $\mathrm{ADF}$ & 27.1 & 16.9 \\
\hline NDF & 36.2 & 27.2 \\
\hline Ether extract & 3.47 & 6.18 \\
\hline Magnesium & 0.46 & 0.32 \\
\hline Potassium & 1.30 & 1.23 \\
\hline Sodium & 0.072 & 0.243 \\
\hline Iron $(\mathrm{mg} / \mathrm{kg})$ & 469 & 570 \\
\hline Zinc $(\mathrm{mg} / \mathrm{kg})$ & 83 & 115 \\
\hline Copper $(\mathrm{mg} / \mathrm{kg})$ & 23 & 23 \\
\hline Manganese (mg/kg) & 65 & 91 \\
\hline Molybdenum (mg/kg) & 0.6 & 0.5 \\
\hline
\end{tabular}

${ }^{1}$ Provided to the diet DM $6.7 \mathrm{~g} / \mathrm{kg}$ of $\mathrm{Ca}$ as calcium propionate, calcium carbonate, and calcium chloride and mono-dicalcium phosphate, $1.4 \mathrm{~g} / \mathrm{kg}$ of $\mathrm{P}$ as mono-dicalcium phosphate, $8.0 \mathrm{~g} / \mathrm{kg}$ of Cl as ammonium chloride and calcium chloride, $3.4 \mathrm{~g} / \mathrm{kg}$ of $\mathrm{Mg}$ as magnesium sulfate, $30 \mathrm{mg} / \mathrm{kg}$ of $\mathrm{K}, 0.99 \mathrm{~g} / \mathrm{kg}$ of S as magnesium, manganese, copper, cobalt, and zinc sulfate, $0.17 \mathrm{mg} / \mathrm{kg}$ of Co as cobalt sulfate, $15.2 \mathrm{mg} / \mathrm{kg}$ of $\mathrm{Cu}$ as copper sulfate, $1.012 \mathrm{mg} / \mathrm{kg}$ of I as ethylenediaminedihydroiodide, $7.7 \mathrm{mg} / \mathrm{kg}$ of $\mathrm{Mn}$ as manganese sulfate, $0.31 \mathrm{mg} /$ $\mathrm{kg}$ of Se as sodium selenite, $29.9 \mathrm{mg} / \mathrm{kg}$ of $\mathrm{Zn}$ as zinc sulfate, $10.8 \mathrm{kIU} / \mathrm{kg}$ of vitamin $\mathrm{A}, 4.6 \mathrm{kIU} / \mathrm{kg}$ of vitamin $\mathrm{D}_{3}, 167 \mathrm{IU} / \mathrm{kg}$ of vitamin $\mathrm{E}$ as all-rac- $\alpha$-tocopheryl acetate, $1.19 \mathrm{~g} / \mathrm{kg}$ of choline, $1.00 \mathrm{~g} / \mathrm{kg}$ of niacin, and 26.8 $\mathrm{mg} / \mathrm{kg}$ of monensin.

${ }^{2}$ Provided to the diet DM $0.30 \mathrm{~g} / \mathrm{kg}$ of $\mathrm{Ca}, 0.23 \mathrm{~g} / \mathrm{kg}$ of P from ammonium polyphosphate, $0.20 \mathrm{~g} / \mathrm{kg}$ of $\mathrm{Mg}$, $1.23 \mathrm{~g} / \mathrm{kg}$ of $\mathrm{K}, 0.21 \mathrm{~g} / \mathrm{kg}$ of Na, $0.19 \mathrm{~g} / \mathrm{kg}$ of Cl, $0.26 \mathrm{~g} / \mathrm{kg}$ of S, $0.07 \mathrm{mg} / \mathrm{kg}$ of Co as cobalt sulfate, $0.05 \mathrm{mg} /$ $\mathrm{kg}$ of $\mathrm{Co}$ as organic cobalt, $12.4 \mathrm{mg} / \mathrm{kg}$ of $\mathrm{Cu}$ as copper sulfate, $4.42 \mathrm{mg} / \mathrm{kg}$ of $\mathrm{Cu}$ as organic copper, $1.76 \mathrm{mg} /$ $\mathrm{kg}$ of I as ethylenediaminedihydroiodide, $10.7 \mathrm{mg} / \mathrm{kg}$ of $\mathrm{Mn}$ as manganese sulfate, $0.81 \mathrm{mg} / \mathrm{kg}$ of $\mathrm{Mn}$ as organic manganese, $0.25 \mathrm{mg} / \mathrm{kg}$ of Se as sodium selenite, $59.0 \mathrm{mg} / \mathrm{kg}$ of Zn as zinc sulfate, $8.00 \mathrm{mg} / \mathrm{kg}$ of Zn as organic zinc, $5.01 \mathrm{kIU} / \mathrm{kg}$ of vitamin $\mathrm{A}, 1.23 \mathrm{kIU} / \mathrm{kg}$ of vitamin $\mathrm{D}_{3}, 24.5 \mathrm{IU} / \mathrm{kg}$ of vitamin $\mathrm{E}$ as all-rac- $\alpha$-tocopheryl acetate, and $0.25 \mathrm{~g} / \mathrm{kg}$ of methionine.

${ }^{3}$ Guaranteed to contain no less than $56 \% \mathrm{Mg}$ (Baymag, Calgary, Canada).

${ }^{4}$ Contained (DM basis) $90.4 \%$ total fat and $9.6 \%$ Ca as calcium salts of long-chain fatty acids from Inman (Clackamas, OR).

Metritis was defined by an odorous vaginal discharge, purulent, and whitish-yellow color. Severity of metritis was classified based on the definitions by Huzzey et al. (2009). The treatment protocol for RP and severe metritis were the same. Cows with mild metritis were treated with $5 \mathrm{~mL}$ of $\mathrm{PGF}_{2 \alpha}$ [Lutalyse (dinoprost tromethamine) injection; $5 \mathrm{mg}$ of Lutalyse Sterile Solution, Pfizer Animal Health; New York, NY] twice, 2 d apart.

Mastitis was diagnosed based on abnormal milk, udder inflammation, and elevated milk SCC (measured
$2 \times /$ wk). If abnormal milk, udder inflammation, or elevated milk SCC $(>1,000$ cells $/ \mu \mathrm{L})$ were detected, a milk sample was collected and on-farm culturing with blood agar was performed. If the quarter was tender but no bacterial growth was detected, $10 \mathrm{~mL}$ of Spectramast $(12.5 \mathrm{mg} / \mathrm{mL}$ ceftiofur hydrochloride $/ \mathrm{mL}$; Pharmacia \& Upjohn, New York, NY) was injected in each affected quarter for $7 \mathrm{~d}$. The same treatment was used for any gram-negative infection except for Staphylococcus aureus infection. If cows had a Staphylococcus 
aureus infection, each affected quarter was injected for $7 \mathrm{~d}$ with $10 \mathrm{~mL}$ of Spectramast or for $3 \mathrm{~d}$ with $10 \mathrm{~mL}$ of Hetacin-K $(6.25 \mathrm{mg} / \mathrm{mL}$ hetacillin potassium equivalent to $6.25 \mathrm{mg}$ of ampicillin; Boehringer Ingelheim Vetmedica Inc., St. Joseph, MO). If cows had a gram-positive Streptococcus infection, cows were injected for $7 \mathrm{~d}$ with $10 \mathrm{~mL}$ of Pirsue (5 mg of pirlimycin hydrochloride/mL; Pharmacia \& Upjohn) in each affected quarter.

Cows were diagnosed as ketotic based on urinary acetoacetate concentrations $>40 \mathrm{mg} / \mathrm{dL}$, as measured with Ketostix strips (Bayer Corp., Elkhart, IN). Cows with ketosis received i.v. $0.5 \mathrm{~L}$ pf dextrose $(50 \%$ dextrose; Aspen Veterinary Resources Ltd.) and orally a 37.85-L drench $[907 \mathrm{~g}$ of Fresh Cow Drench (TPi, Madera, CA) and $237 \mathrm{~mL}$ of propylene glycol dissolved in $37.85 \mathrm{~L}$ of water]. If cows were not eating, they received in addition i.m. $20 \mathrm{~mL}$ of vitamin B complex (Aspen Veterinary Resources Ltd.) and orally 2 capsules of Pecti-cap (Bio-Vet Inc., Blue Mounds, WI).

Laminitis was diagnosed if a cow had an abnormal gait, did not bear weight on each foot equally, or was sensitive to touch on the foot. If cows were lame, the hoof was trimmed. Depending on severity, a wrap or a block was applied. If significant swelling was present, cows were injected in mild cases with $20 \mathrm{~mL}$ of Ceftioflex (ceftiofur sodium sterile powder; Med-Pharmex) or Excede (200 mg ceftiofur/mL; Pharmacia \& Upjohn) for 1 to $3 \mathrm{~d}$. In cases with infections, cows were moved into the hospital pen and received i.m. $40 \mathrm{~mL}$ of penicillin for up to $7 \mathrm{~d}$, and then were injected i.m. with $30 \mathrm{~g}$ of sulfadimethoxine for up to $7 \mathrm{~d}$. If the cows were in pain, they received $30 \mathrm{~mL}$ i.m. of Banamine injectable solution (50 mg flunixin meglumine/mL; Aspen Veterinary Resources Ltd.) and orally 3 tablets of Aspirin Bolus (15.6 g of acetyl salicylic acid/per tablet; 240 grains; Merrick's Inc., Middleton, WI).

Cows were diagnosed to have milk fever if they showed signs as described by Kelton et al. (1998). Cows with milk fever remained in the hospital pen and received i.v. 0.5 L of CMPK (calcium-magnesium-phosphorus-potassium-dextrose solution; Aspen Veterinary Resources Ltd.) and 0.5 L of dextrose (50\% dextrose; Aspen Veterinary Resources Ltd.) and orally a $37.85-\mathrm{L}$ drench [907 g of Fresh Cow Drench (TPi) and $237 \mathrm{~mL}$ of propylene glycol dissolved in $37.85 \mathrm{~L}$ of water]. Cows were diagnosed to have left displaced abomasum if they showed signs as described by Kelton et al. (1998). We had previously described the treatment for left displaced abomasum (Qu et al., 2013b).

The RP incidence rate in this study cohort was $19.9 \%$ (32 of 161 cows). Cows with RP were in their second to fifth parity and had RP for 1 (3 cows), 2 (2 cows), 3 (1 cow), 4 (2 cows), 5 (4 cows), 6 (4 cows), 7 (4 cows), 8 (6 cows), 9 (4 cows), 10 (1 cow), and $11 \mathrm{~d}$ (1 cow) from calving. Of the $32 \mathrm{RP}$ cows, 22 cows had calved at least $5 \mathrm{~d}$ early (range -5 to $-19 \mathrm{~d}$ before predicted calving date), 16 cows had twins, 5 cows had dystocia (hard pull; 1 cow had a twisted uterus), and 8 cows appeared sluggish after calving. Except for $1 \mathrm{RP}$ cow, all other RP cows displayed one or more of the previously described symptoms. In the following $28 \mathrm{~d}$, all RP cows were treated for severe metritis, 4 cows for laminitis $(2$ without antibiotics and 2 requiring antibiotics), 3 cows for mastitis (2 gram-positive, 1 gram-negative), 2 cows for ketosis, 2 cows for milk fever, and 1 cow for left displaced abomasum. The $32 \mathrm{H}$ cows did not show signs of clinical diseases during the first $28 \mathrm{~d}$ postpartum. The 32 OD cows were treated for the following diseases during the first $28 \mathrm{~d}$ postpartum: 23 cows were treated for metritis ( 7 for severe metritis and 16 for mild metritis), 10 cows for mastitis (3 gram-negative, 2 gram-positive, and 5 no growth on blood agar) and ketosis each, and 9 cows for laminitis (6 cases without antibiotics and 3 requiring antibiotics).

\section{Blood Collection}

Blood samples were taken at d $-21(-24$ to -18$)$, $-14(-17$ to -11$),-7$ ( -10 to -5$),-3$ ( -4 or -3$),-1$ $(-2$ or -1$), 0,1,3,7,14,21,28,35,42$, and 49 postpartum within $10 \mathrm{~min}$ after morning feeding. Blood (5 to $8 \mathrm{~mL}$ ) was obtained from the coccygeal vein or artery in 10-mL serum Vacutainer tubes (BD Diagnostics, Franklin Lakes, NJ), placed on ice, and transported to the laboratory, where serum was separated by centrifugation at room temperature for $20 \mathrm{~min}$ at 1,600 $\times$ g. Serum samples were stored at $-20^{\circ} \mathrm{C}$ until chemical analysis.

\section{Serum Analysis}

Serum concentrations of $\alpha$-tocopherol were measured using reversed-phase HPLC with electrochemical detection, as previously described ( $\mathrm{Qu}$ et al., 2013b). The plasma sample volume was $100 \mu \mathrm{L}$ per test, which was extracted following saponification with alcoholic $\mathrm{KOH}$ in the presence of $1 \%$ ascorbic acid. The peak areas of the tocopherol contents in the sample extracts were compared with those of authentic compounds; a standard curve was performed daily. All samples were tested once, and the test was repeated if the results were inconsistent with the results of the same cow at other time points. The inter- and intraassay coefficients of variation (CV) were 4.97 and $3.34 \%$, respectively.

Commercially available kits were used to measure serum concentrations of cholesterol (Stanbio Cholesterol LiquiColor Procedure No. 1010, Stanbio Laboratory, Boerne, TX), glucose (Stanbio Glucose Proc. No. 1075, 
Stanbio Laboratory), NEFA (ACS ACOD method, Wako Diagnostics, Richmond, VA), BHBA (Stanbio BHBA LiquiColor Proc. No. 2440, Stanbio Laboratory), urea N (Stanbio Urea Nitrogen Liqui-UV Proc. No. 2020, Stanbio Laboratory), haptoglobin (cat. no. 241070, Life Diagnostics Inc., West Chester, PA), calcium (Stanbio Total Calcium LiquiColor Proc. No. 0150, Stanbio Laboratory), magnesium (Stanbio Magnesium LiquiColor Proc. No. 0130, Stanbio Laboratory), and phosphorus (Stanbio Phosphorus Liqui-UV Proc. No. 0830, Stanbio Laboratory) according to the manufacturer's instructions. The sample volume per test was $5 \mu \mathrm{L}$ for cholesterol, haptoglobin, and magnesium and $10 \mu \mathrm{L}$ for glucose, NEFA, BHBA, urea N, calcium, and phosphorus. Samples were not diluted except for haptoglobin, which was diluted 2,000-fold in 3 dilution steps, as recommended by the manufacturer. Absorbance was measured with a FLUOstar Omega microplate autoreader (BMG Labtech Inc., San Francisco, CA). Samples were tested in duplicate, and the test was repeated as duplicate if the results for the first 2 samples differed by $\geq 12 \%$. Haptoglobin concentrations were tested once and the test was repeated if the results were inconsistent with the results of the same cow at other time points. The inter- and intraassay CV were 2.26 and $5.18 \%$ for cholesterol, 0.98 and $1.24 \%$ for glucose, 4.69 and $3.32 \%$ for NEFA, 3.59 and $3.38 \%$ for BHBA, 1.68 and $1.20 \%$ for urea N, 3.79 and $3.92 \%$ for haptoglobin, 4.23 and $4.19 \%$ for calcium, 4.87 and $3.86 \%$ for magnesium, and 2.59 and $4.29 \%$ for phosphorus.

\section{Statistical Analysis}

Data were analyzed as repeated-measures-in-time ANOVA study using PROC MIXED of SAS (version 9.2; SAS Institute, 2009). The molar ratio of $\alpha$-tocopherol to cholesterol was calculated to adjust for changes in lipid concentrations (Traber and Jialal, 2000) and stage of lactation (Weiss, 1998). Normality of data distribution was evaluated using the Shapiro-Wilk test in PROC UNIVARIATE. Because the Shapiro-Wilk test is very sensitive to deviations from normality, we tested several distributions (nontransformed, square root, ln, and twice $\ln$ ) and chose the transformation that resulted in the highest $\mathrm{W}$ value. Concentrations of glucose, NEFA, and the $\alpha$-tocopherol to cholesterol molar ratio were ln-transformed, concentrations of haptoglobin and BHBA were twice ln-transformed, and concentrations of cholesterol were square-root-transformed. Phosphorus concentrations had outliers at high concentrations; thus, concentrations $>11 \mathrm{mg} / \mathrm{dL}$ (14 samples in 13 cows) were set at $11 \mathrm{mg} / \mathrm{dL}$. The variance-covariance structure of repeated measures within cow was modeled using the heterogeneous first-order autoregressive variance-covariance matrix. Fixed effects were group $(\mathrm{H}, \mathrm{OD}$, and RP), parity $(2,>2)$, sampling time, and the interaction between group and sampling time. We did not include season of calving in the final model, because it was not significant. To obtain the correct degrees of freedom, the KENWARDROGER option was invoked. The results of the PROC MIXED analysis are shown in Figures 1 to 4.

To compare our results with previously published studies and to identify early risk indicators of RP, OD, or both, average serum concentrations in the last $3 \mathrm{wk}$ and in the last week before calving were calculated using the trapezoidal rule and analyzed in PROC GLM with group and parity as fixed effects. The same statistical model was used to compare groups between 3 and $2 \mathrm{wk}$ before calving (average of 3 and 2 wk prepartum) and the morning after calving. The results of the PROC GLM analysis are shown in Table 2 and for the last 3 wk before calving in the text. We considered concentrations that differed throughout precalving or between wk 3 and 2 precalving as better risk indicators than those for the last week precalving or at a single time point, because the former were more consistent and provided more time for treatment. To determine if and for how long serum concentrations were changed, we averaged serum concentrations for wk 2 to 4 postpartum and wk 5 to 7 postpartum and analyzed in PROC GLM with group and parity as fixed effects.

Values presented in the figures and tables are least squares means and standard errors of the mean that are transformed back to their original measurement scale. The 2 a priori comparisons were $\mathrm{RP}$ versus $\mathrm{H}$ cows (to evaluate whether the serum analyte was sensitive to predict $\mathrm{RP}$ ) and $\mathrm{RP}$ versus $\mathrm{OD}$ cows (to determine whether the serum analyte is specific to RP). In a posteriori comparison, $\mathrm{OD}$ and $\mathrm{H}$ cows were compared. We used the Bonferroni correction to adjust for the 3 comparisons. All statistical tests were 2-sided. Significance was declared at $P \leq 0.05$ and a tendency at 0.05 to 0.10 .

\section{RESULTS}

\section{Serum $\alpha$-Tocopherol, Cholesterol, and RP}

Serum concentrations of $\alpha$-tocopherol and cholesterol in the peripartal period in relation to cow health are shown in Figure 1. Serum $\alpha$-tocopherol concentrations were lower in all cows group during the first week postpartum (Figure 1a). During most of the peripartal period, serum concentrations of $\alpha$-tocopherol were lower for RP and OD cows than for $\mathrm{H}$ cows and did not differ between RP and OD cows (Figure 1a). Prepartum, RP cows had, on average, lower $\alpha$-tocopherol concentra- 
Table 2. Comparison of serum concentrations between cows that developed retained placenta (RP) or other diseases (OD), or remained healthy (H) during the first $28 \mathrm{~d}$ postpartum

\begin{tabular}{|c|c|c|c|c|c|c|}
\hline Indicator & \multicolumn{3}{|c|}{ Group } & \multicolumn{3}{|c|}{ Contrast ( $P$-value $)$} \\
\hline Cholesterol (mg/dL) & $116 \pm 4$ & $114 \pm 4$ & $105 \pm 4$ & 0.13 & 0.23 & 1.00 \\
\hline ATOC:cholesterol $^{1}$ & $4.01 \pm 0.22$ & $3.32 \pm 0.18$ & $3.12 \pm 0.17$ & 0.002 & 0.61 & 0.02 \\
\hline $\operatorname{NEFA}(\mu \mathrm{Eq} / \mathrm{L})$ & $184 \pm 16$ & $253 \pm 23$ & $300 \pm 27$ & $<0.001$ & 0.23 & 0.02 \\
\hline Glucose $(\mathrm{mg} / \mathrm{dL})$ & $70.4 \pm 1.0$ & $68.3 \pm 1.0$ & $67.2 \pm 1.0$ & 0.04 & 0.63 & 0.23 \\
\hline Urea $N(\mathrm{mg} / \mathrm{dL})^{\prime}$ & $10.9 \pm 0.4$ & $10.9 \pm 0.5$ & $10.2 \pm 0.5$ & 0.58 & 0.51 & 1.00 \\
\hline Calcium (mg/dL) & $8.82 \pm 0.11$ & $9.12 \pm 0.11$ & $8.78 \pm 0.11$ & 1.00 & 0.04 & 0.09 \\
\hline Magnesium (mg/dL) & $2.61 \pm 0.04$ & $2.52 \pm 0.05$ & $2.48 \pm 0.05$ & 0.07 & 0.72 & 0.27 \\
\hline Phosphorus (mg/dL) & $7.20 \pm 0.11$ & $7.15 \pm 0.12$ & $6.70 \pm 0.12$ & 0.005 & 0.008 & 1.00 \\
\hline \multicolumn{7}{|l|}{ Last week prepartum } \\
\hline$\alpha$-Tocopherol $(\mu M)$ & $12.6 \pm 0.6$ & $9.4 \pm 0.6$ & $8.6 \pm 0.6$ & $<0.001$ & 0.48 & $<0.001$ \\
\hline Glucose $(\mathrm{mg} / \mathrm{dL})$ & $71.2 \pm 1.3$ & $67.3 \pm 1.3$ & $65.3 \pm 1.3$ & 0.003 & 0.36 & 0.06 \\
\hline Urea N (mg/dL) & $10.6 \pm 0.5$ & $10.7 \pm 0.6$ & $11.0 \pm 0.6$ & 1.00 & 1.00 & 1.00 \\
\hline Calcium (mg/dL) & $8.78 \pm 0.17$ & $8.64 \pm 0.17$ & $8.64 \pm 0.17$ & 0.85 & 1.00 & 0.84 \\
\hline Magnesium (mg/dL) & $2.68 \pm 0.06$ & $2.47 \pm 0.06$ & $2.46 \pm 0.06$ & 0.01 & 1.00 & 0.02 \\
\hline Phosphorus (mg/dL) & $6.74 \pm 0.16$ & $6.83 \pm 0.17$ & $6.66 \pm 0.17$ & 1.00 & 0.66 & 1.00 \\
\hline \multicolumn{7}{|l|}{ Morning after calving } \\
\hline$\alpha$-Tocopherol $(\mu M)$ & $10.3 \pm 0.5$ & $7.7 \pm 0.5$ & $7.1 \pm 0.5$ & $<0.001$ & 0.61 & $<0.001$ \\
\hline Cholesterol (mg/dL) & $94 \pm 4$ & $88 \pm 4$ & $91 \pm 4$ & 0.97 & 0.97 & 0.55 \\
\hline ATOC:cholesterol & $4.15 \pm 0.22$ & $3.22 \pm 0.18$ & $2.94 \pm 0.16$ & $<0.001$ & 0.33 & 0.002 \\
\hline NEFA $(\mu \mathrm{Eq} / \mathrm{L})$ & $325 \pm 31$ & $496 \pm 49$ & $545 \pm 54$ & $<0.001$ & 0.71 & 0.003 \\
\hline BHBA $(\mathrm{mmol} / \mathrm{L})$ & $0.69 \pm 0.04$ & $0.71 \pm 0.04$ & $0.75 \pm 0.04$ & 0.49 & 0.71 & 1.00 \\
\hline Haptoglobin $(\mathrm{mg} / \mathrm{L})$ & $24.2 \pm 5.0$ & $44.5 \pm 11.4$ & $34.1 \pm 8.0$ & 0.88 & 0.34 & 0.06 \\
\hline Glucose $(\mathrm{mg} / \mathrm{dL})$ & $69.2 \pm 2.6$ & $75.1 \pm 2.9$ & $85.7 \pm 3.3$ & $<0.001$ & 0.02 & 0.20 \\
\hline Urea N (mg/dL) & $12.2 \pm 0.7$ & $13.7 \pm 0.8$ & $14.4 \pm 0.8$ & 0.10 & 0.96 & 0.38 \\
\hline
\end{tabular}

${ }^{1}$ ATOC:cholesterol $=\alpha$-tocopherol to cholesterol molar ratio $(\mathrm{mmol} / \mathrm{mol})$.

tions than $\mathrm{H}$ cows $(8.7 \pm 0.6$ vs. $12.5 \pm 0.5 \mu M ; P<$ 0.001); group differences were large (approximately $44 \%$ lower in RP cows), consistent, and present throughout the prepartal sampling period. At 3 wk prepartum, RP cows also tended to have lower $\alpha$-tocopherol concentrations than OD cows $(P=0.06$; Figure 1a). Differences in serum $\alpha$-tocopherol concentrations between OD and $\mathrm{H}$ cows started a week later (2 wk precalving) than those between RP and $\mathrm{H}$ cows and remained significant until d 49 postpartum. No group differences in serum cholesterol concentrations were observed prepartum (Figure 1b). At d 7 postcalving, RP and OD cows had significantly lower concentrations than $\mathrm{H}$ cows, a finding that persisted until the end of the sampling period (d 49 postpartum). At d 21 postpartum, RP cows had lower serum cholesterol concentrations than OD cows. Cows with $\geq 2$ completed parities had lower serum cholesterol concentrations than cows with 1 completed parity $(P<0.001)$.

\section{Energy Status and RP}

Serum concentrations of NEFA and BHBA as well as BCS in the peripartal period in relation to cow health are shown in Figure 2. Serum NEFA concentrations were elevated in the week around calving for all cow groups (Figure 2a), with NEFA concentrations increasing earlier in RP and OD cows than in $\mathrm{H}$ cows. Between d 3 and 14 postpartum, serum NEFA concentrations were lower for RP cows than for $\mathrm{H}$ cows. Cows with $\geq 2$ completed parities tended to have higher NEFA concentrations than cows with 1 completed parity $(P$ $=0.08$ ). Serum BHBA concentrations were elevated in the first week after calving for all cow groups (Figure 2b). Overall, BHBA concentrations were higher for RP cows than for $\mathrm{H}$ cows $(P=0.05)$. Significant group differences were exclusively observed in the prepartal period (Figure 2b). On average, BHBA concentrations were higher for $\mathrm{RP}$ cows than for $\mathrm{H}$ cows during the 


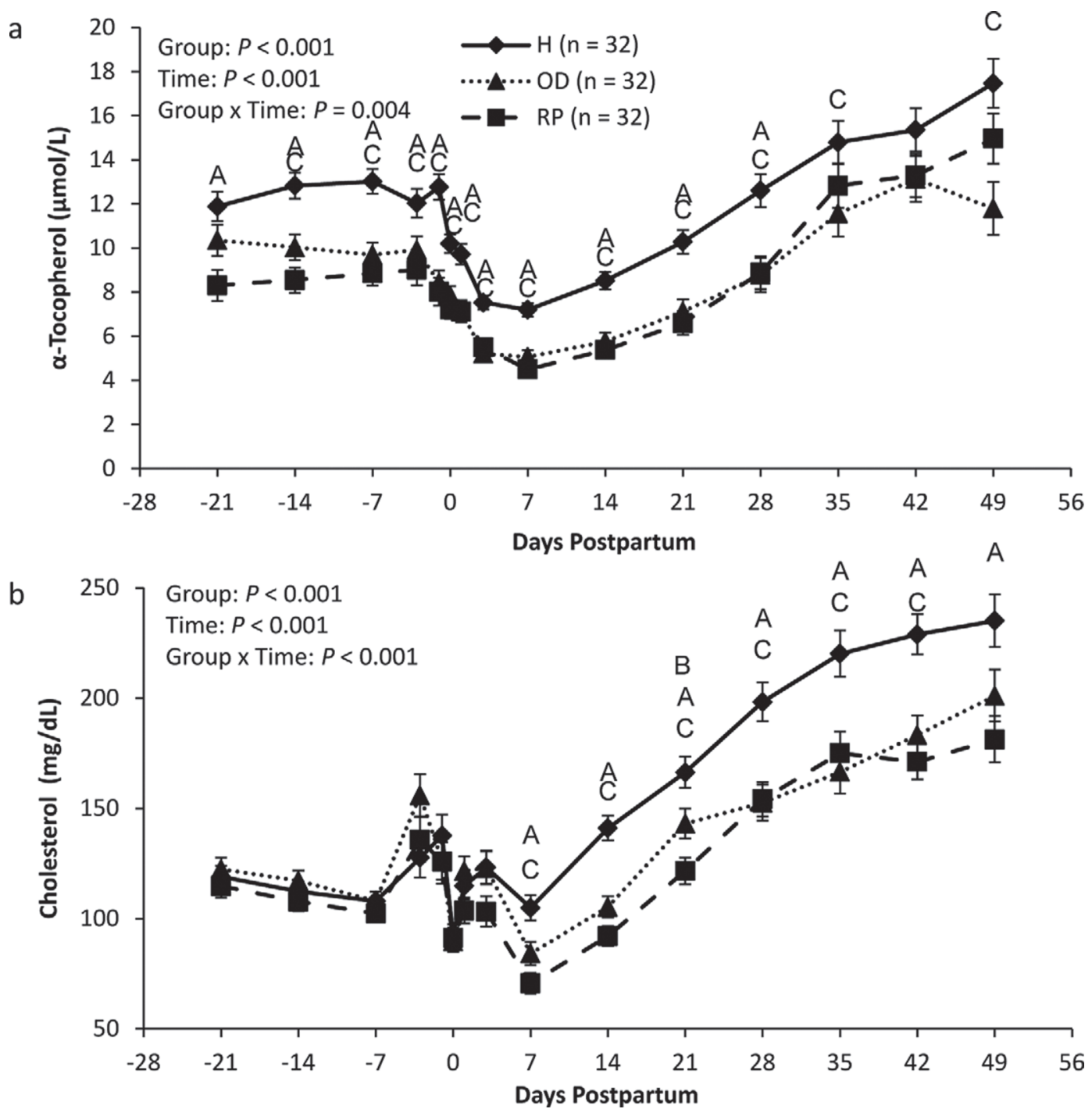

Figure 1. Serum concentrations (LSM \pm SEM) of (a) $\alpha$-tocopherol and (b) cholesterol between d -21 and 49 postpartum in healthy cows $(\mathrm{H})$, cows with other diseases $(\mathrm{OD})$, and cows with retained placenta $(\mathrm{RP})$. Letters indicate differences $(P \leq 0.05)$ at the indicated time point: $\left({ }^{\mathrm{A}}\right)$ between $\mathrm{RP}$ and $\mathrm{H}$ cows, $\left({ }^{\mathrm{B}}\right)$ between $\mathrm{RP}$ and $\mathrm{OD}$ cows, and $\left(^{\mathrm{C}}\right)$ between $\mathrm{OD}$ and $\mathrm{H}$ cows.

prepartal period $(0.57 \pm 0.02$ vs. $0.45 \pm 0.02 \mathrm{mmol} / \mathrm{L}$; $P<0.001)$, with intermediate concentrations for OD cows $(0.51 \pm 0.02 \mathrm{mmol} / \mathrm{L} ; P=0.04$ vs. $\mathrm{RP}$ and $\mathrm{H}$ cows, respectively). The RP cows had lower BCS than the $\mathrm{H}$ cows until 7 wk postpartum and lower BCS than the OD cows until 2 wk postpartum (Figure 2b). Starting 2 wk postpartum, OD cows had or tended to have lower BCS than $\mathrm{H}$ cows (Figure 2c). The decrease in BCS from wk 4 prepartum to wk 4 postpartum was greater in RP and OD cows than in $\mathrm{H}$ cows $(-1.19 \pm$ 0.10 and $-1.15 \pm 0.10$ vs. $-0.80 \pm 0.09 ; P=0.006$ and $P=0.01$, respectively). No significant differences in BCS changes between cow groups were observed before calving $(\mathrm{H}:-0.07 \pm 0.04$; OD: $-0.15 \pm 0.04$; RP: $-0.16 \pm 0.05)$.

\section{Inflammation Status and RP}

Serum concentrations of haptoglobin, glucose, and urea $\mathrm{N}$ in the peripartal period in relation to cow health are shown in Figure 3. Haptoglobin concentrations were elevated during the first week after calving for all cow groups, with higher and more persistent higher concentrations for $\mathrm{OD}$ and $\mathrm{RP}$ cows than for $\mathrm{H}$ cows (Figure $3 a$ a). Cows with $\geq 2$ completed parities tended to have higher haptoglobin concentrations than cows with 1 completed parity $(P=0.08)$. Serum glucose concentrations were elevated around calving for all cow groups, with higher concentrations at $\mathrm{d} 0$ and 3 postpartum for $\mathrm{RP}$ cows than for OD and $\mathrm{H}$ cows (Figure $3 \mathrm{~b}$ ). The RP cows had, on average, lower serum glucose concentra- 


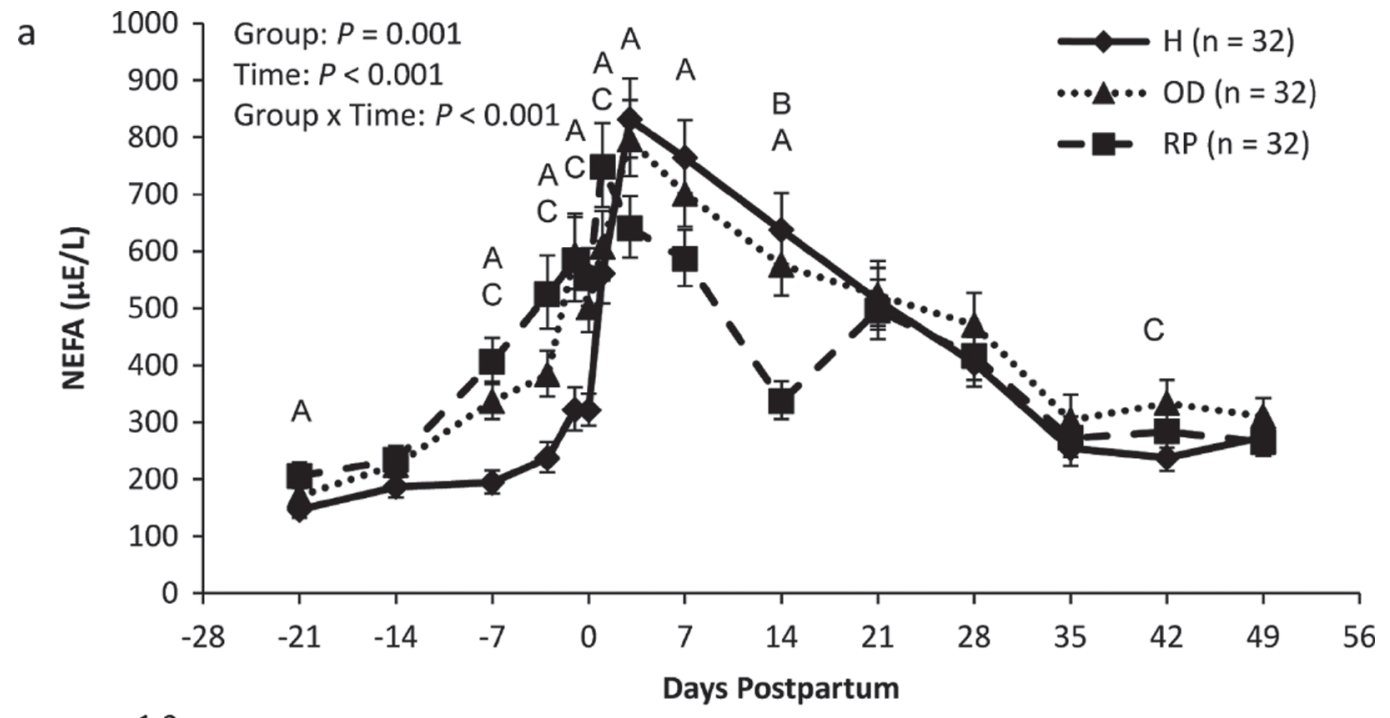

b
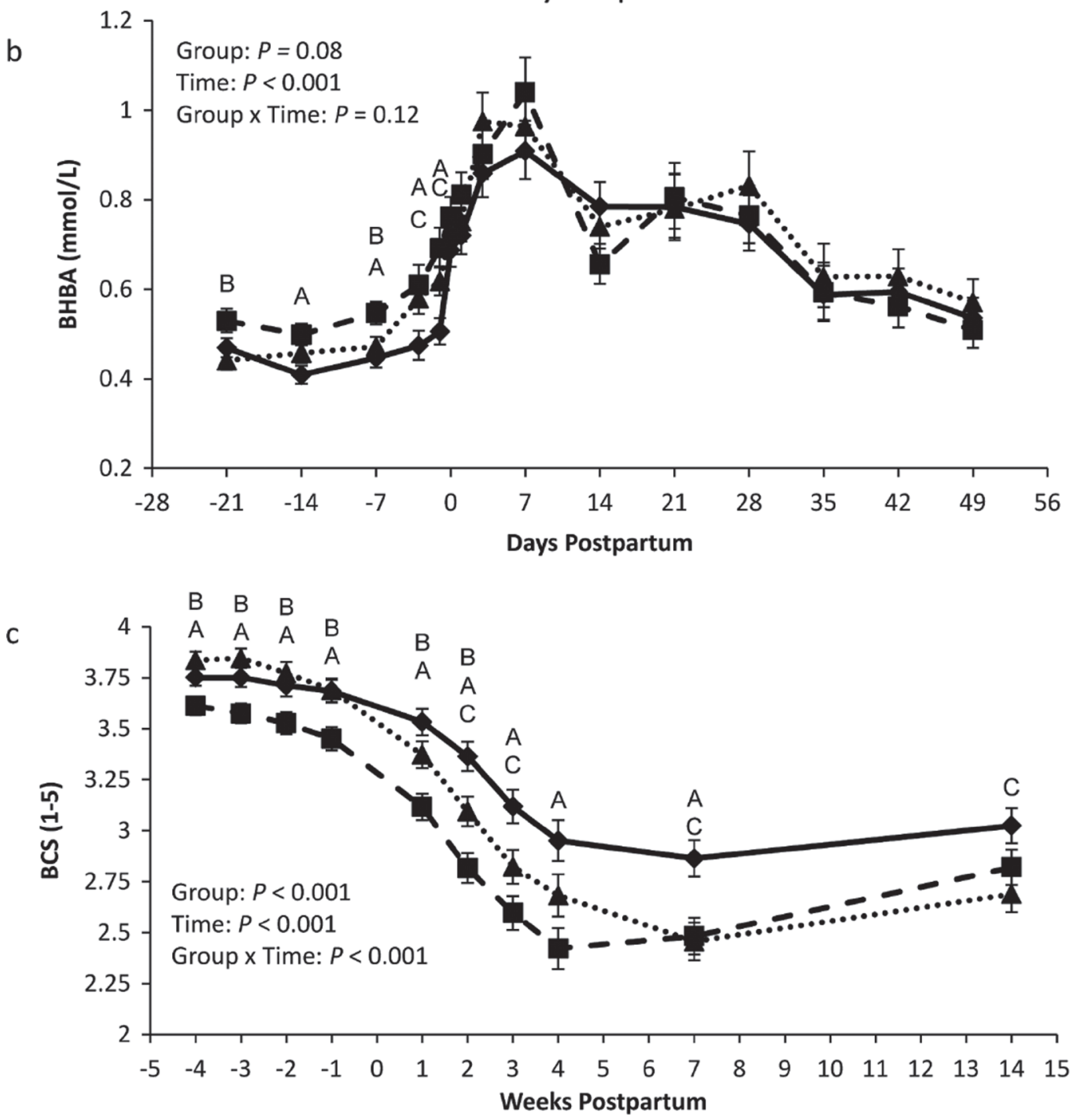

Figure 2. Serum concentrations (LSM \pm SEM) of (a) NEFA and (b) BHBA between $d-21$ and 49 postpartum and (c) BCS between wk -4 to 14 postpartum in healthy cows $(\mathrm{H})$, cows with other diseases $(\mathrm{OD})$, and cows with retained placenta $(\mathrm{RP})$. Letters indicate differences $(P \leq$ $0.05)$ at the indicated time point: $\left(^{\mathrm{A}}\right)$ between RP and H cows, $\left({ }^{\mathrm{B}}\right)$ between RP and OD cows, and $\left({ }^{\mathrm{C}}\right)$ between OD and $\mathrm{H}$ cows. 
tions during the prepartum period than did $\mathrm{H}$ cows $(67.3 \pm 1.0$ vs. $70.9 \pm 1.0 \mathrm{mg} / \mathrm{dL} ; P=0.02)$. Serum urea $\mathrm{N}$ concentrations were elevated during the first days postpartum for OD and RP but not for $\mathrm{H}$ cows (Figure 3c). Between 14 and $42 \mathrm{~d}$ postpartum, serum urea $\mathrm{N}$ concentrations were or tended to be lower for $\mathrm{OD}$ and RP cows than for $\mathrm{H}$ cows.

\section{Macromineral Status and RP}

Serum concentrations of calcium, magnesium, and phosphorus in the peripartal period in relation to cow health are shown in Figure 4. During the first day after calving, serum calcium concentrations were decreased for all cow groups (Figure 4a). Serum calcium concentrations started to increase later for RP than $\mathrm{H}$ cows. Serum magnesium concentrations were elevated the first day postpartum and were then decreased at d 7 postpartum for all cow groups (Figure 4b). Serum magnesium concentrations were lower for RP and OD cows than $\mathrm{H}$ cows at 7 and $3 \mathrm{~d}$ precalving and 7 to 28 $\mathrm{d}$ postcalving. Serum phosphorus concentrations were decreased during the first week postpartum for all cow groups (Figure 4c). Serum phosphorus concentrations were or tended to be lower for RP than $\mathrm{H}$ cows at 21 and $14 \mathrm{~d}$ prepartum, respectively, and serum phosphorus concentrations were lower for RP than OD cows at 21 and $7 \mathrm{~d}$ prepartum. Cows with $\geq 2$ completed parities had lower calcium and phosphorus concentrations than cows with 1 completed parity (both $P<0.001$ ).

\section{Early Serum Indicators of RP and $O D$}

To identify early indicators of RP, OD, or both, we compared the average serum concentrations of the 3 cow groups during 3 periods preceding RP diagnosis (3 to 2 wk precalving, last week precalving, and morning after calving; Table 2). During the prepartal periods, $\mathrm{RP}$ and OD cows had lower $\alpha$-tocopherol concentrations (corrected or not for cholesterol concentrations) and higher NEFA and BHBA concentrations than $\mathrm{H}$ cows. Between 3 and 2 wk precalving, RP cows had lower serum $\alpha$-tocopherol, glucose, and phosphorus concentrations, as well as higher NEFA and BHBA concentrations than $\mathrm{H}$ cows and tended to have or had lower $\alpha$-tocopherol and phosphorus concentrations as well as higher BHBA concentrations than OD cows. The OD cows had lower serum $\alpha$-tocopherol concentrations and higher NEFA concentrations compared with the $\mathrm{H}$ cows.

During the last week prepartum, RP and OD cows had or tended to have lower $\alpha$-tocopherol, glucose, and magnesium concentrations and higher NEFA and
BHBA concentrations than $\mathrm{H}$ cows (Table 2). During the last week prepartum and on the morning after calving, OD cows tended to have higher haptoglobin concentrations than $\mathrm{H}$ cows. The RP cows had higher glucose concentrations than $\mathrm{OD}$ or $\mathrm{H}$ cows the morning after calving (Table 2).

\section{DISCUSSION}

The primary objective of this study was to identify potential early risk indicators of RP, OD, or both, in multiparous dairy cows. During the 3 wk precalving, RP cows had lower serum $\alpha$-tocopherol concentrations (corrected or not corrected for serum cholesterol concentrations) than H cows (Figure 1a, Table 2). Similarly, LeBlanc et al. (2004) reported, using data from a large vitamin E supplementation trial (LeBlanc et al., 2002), that cows that developed RP had, in the last week prepartum, lower serum $\alpha$-tocopherol concentrations than cows that did not develop RP. However, that study did not distinguish between $\mathrm{H}$ and $\mathrm{OD}$ cows and did not evaluate how long the $\alpha$-tocopherol concentrations differed between $\mathrm{H}$ and OD cows. Our study suggests that lower serum $\alpha$-tocopherol concentrations may also precede OD but that group differences between OD and $\mathrm{H}$ cows are observed up to $7 \mathrm{~d}$ later than those between RP and $\mathrm{H}$ cows. As a result, RP cows tended to have lower serum $\alpha$-tocopherol concentrations between 3 and 2 wk prepartum than OD cows (Table 2). We reported previously that lower serum $\alpha$-tocopherol concentrations and $\alpha$-tocopherol:cholesterol molar ratios preceded left displaced abomasum and milk fever (Qu et al., 2013a,b), suggesting a common disorder associated with lower serum $\alpha$-tocopherol concentrations that increases the risk of diseases in early lactation.

One potential reason for the lower prepartal serum $\alpha$-tocopherol concentrations in RP and later in $\mathrm{OD}$ cows compared with $\mathrm{H}$ cows is lower feed intake. A major limitation for the interpretation of our serum data is that we did not measure DMI; however, we can utilize NEFA, BHBA, glucose, and BCS data as indicators of energy balance (Moyes et al., 2013). The RP and OD cows had precalving higher serum NEFA and BHBA concentrations than $\mathrm{H}$ cows (Table 2), as the prepartal increase in NEFA and BHBA concentrations began earlier in cows with RP and OD cows than $\mathrm{H}$ cows (Figures 2a, 2b). Similarly, NEFA concentrations $>300$ to $500 \mu \mathrm{Eq} / \mathrm{L}$ have been reported as early predictors of RP and OD in large, multi-herd field trials in the last week prepartum (Ospina et al., 2010; Chapinal et al., 2011; Moyes et al., 2013), suggesting a lower prepartal energy balance as a risk indicator for diseases in early lactation, as supported by data from Moyes et 

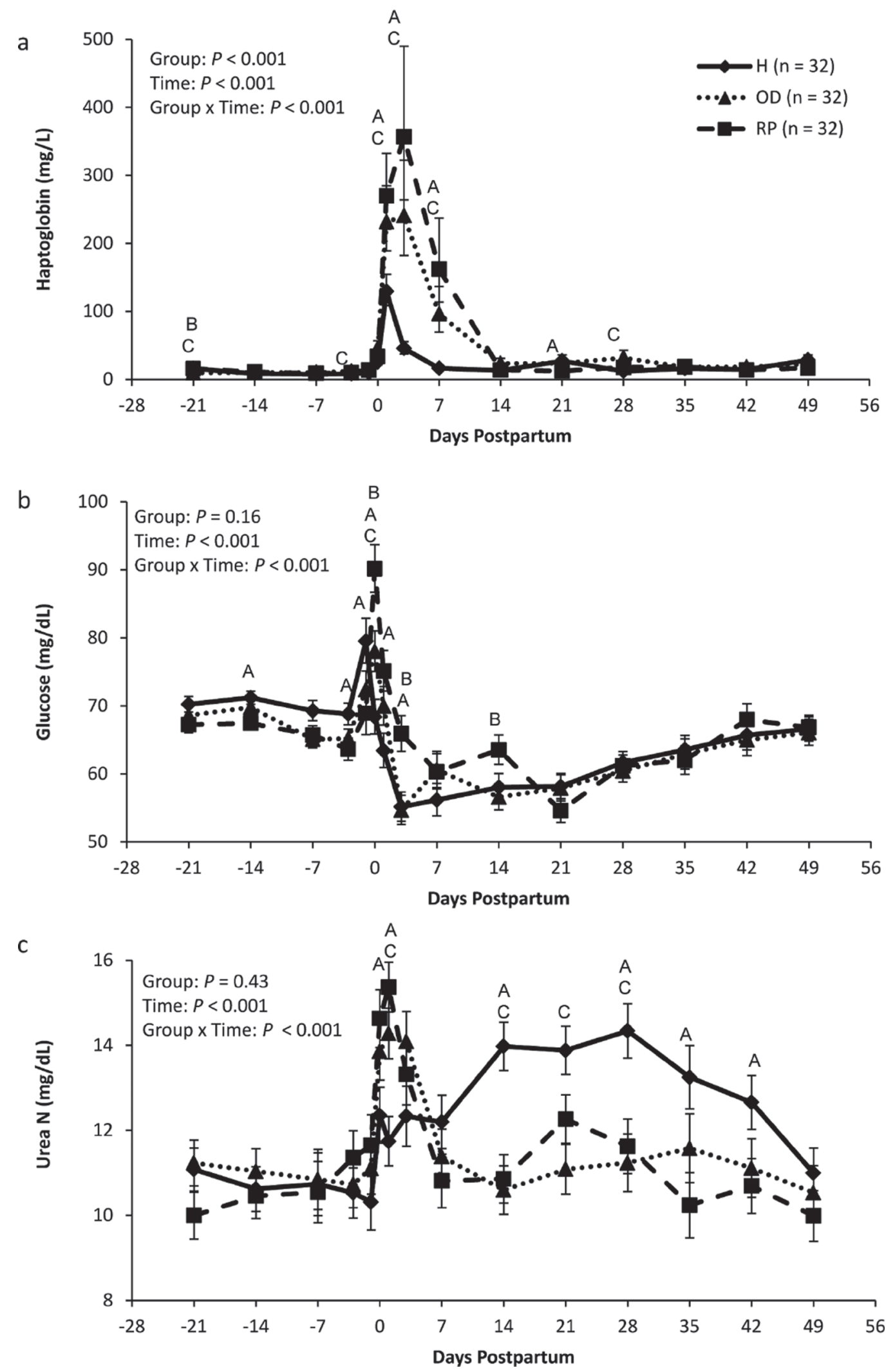

Figure 3. Serum concentrations (LSM \pm SEM) of (a) haptoglobin, (b) glucose, and (c) urea N between d -21 and 49 postpartum in healthy cows $(\mathrm{H})$, cows with other diseases $(\mathrm{OD})$, and cows with retained placenta $(\mathrm{RP})$. Letters indicate differences $(P \leq 0.05)$ at the indicated time point: $\left(^{\mathrm{A}}\right)$ between RP and $\mathrm{H}$ cows, $\left({ }^{\mathrm{B}}\right)$ between RP and OD cows, and $\left({ }^{\mathrm{C}}\right)$ between OD and $\mathrm{H}$ cows. 

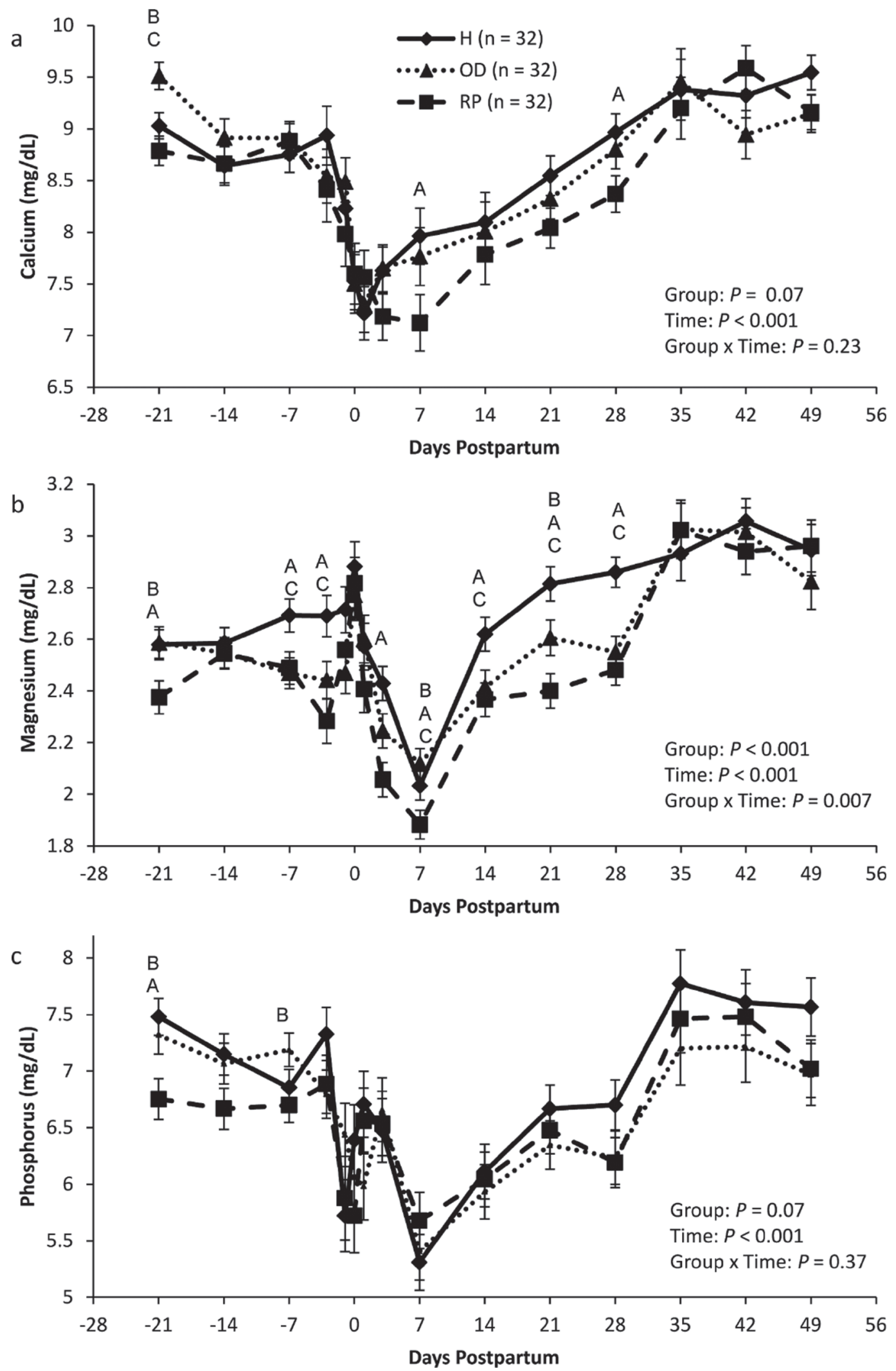

Figure 4. Serum concentrations (LSM $\pm \mathrm{SEM}$ ) of (a) calcium, (b) magnesium, and (c) phosphorus between d -21 and 49 postpartum in healthy cows $(\mathrm{H})$, cows with other diseases $(\mathrm{OD})$, and cows with retained placenta $(\mathrm{RP})$. Letters indicate differences $(P \leq 0.05)$ at the indicated time point: ( ${ }^{\mathrm{A}}$ ) between RP and H cows, $\left({ }^{\mathrm{B}}\right)$ between RP and OD cows, and $\left({ }^{\mathrm{C}}\right)$ between OD and $\mathrm{H}$ cows. 
al. (2013). In support, RP and OD cows had or tended to have lower glucose concentrations during the last week precalving (Table 2).

In several smaller studies, no differences in prepartal NEFA concentrations were observed between cows with or without RP (Kaneene et al., 1997; Quiroz-Rocha et al., 2009; Seifi et al., 2011). Furthermore, several studies did not report BHBA differences between cows with and without RP (Quiroz-Rocha et al., 2009; Chapinal et al., 2011; Seifi et al., 2011). Those studies, however, often did not distinguish between $\mathrm{H}$ and OD cows. Furthermore, most studies group samples by week in relation to calving. As NEFA and BHBA concentrations rapidly increase during the last week precalving in all cows, $\mathrm{H}$ cows could have high concentrations because they calve on the next day.

The results for BCS are intriguing: RP cows had consistently lower BCS during the prepartal period than did OD or $\mathrm{H}$ cows (Figure 2c). The lower BCS in RP cows can be explained in part by the greater incidence of twin calves in RP (16 cows) than in OD (2 cows) or $\mathrm{H}$ cows (1 cow), a known risk factor for RP (reviewed in Laven and Peters, 1996; Drillich, 2011), which resulted in greater nutrient and energy requirements in late gestation. However, other risk factors of RP (e.g., dystocia and fatty liver) are associated with obesity (Laven and Peters, 1996; Drillich, 2011). In support, BCS $\leq 3$ and BCS $\geq 3.75$ in the late dry period are associated with increased risk of RP (Zhang et al., 2002). In our study, only 6 of the 30 cows with prepartal BCS $\geq 3.75$ developed RP, whereas 20 developed OD and 14 remained $\mathrm{H}$; however, only 4 of the 30 cows had dystocia. Based on the group differences in NEFA, BHBA, and glucose concentrations precalving, we would expect that RP and OD cows would lose more BCS during the prepartal period than $\mathrm{H}$ cows, which was not the case, suggesting that visible fat stores (e.g., back fat) were not affected. Similar to $\alpha$-tocopherol, BCS was relatively constant before calving (Figure 2c). In contrast to $\alpha$-tocopherol, OD and $\mathrm{H}$ cows had similar BCS prepartum, and group differences between RP and OD cows remained similar during the prepartal period (Figure 2c), which suggests lower BCS is a specific RP risk indicator.

Uterine infections and an imbalanced immune response are thought to be involved in RP development (McNaughton and Murray, 2009; Drillich, 2011). Haptoglobin is a major positive acute phase protein in dairy cattle, whose secretion is induced by proinflammatory cytokines (Cray et al., 2009). Haptoglobin concentrations are elevated in cows with metabolic and infectious diseases (Ametaj et al., 2011), including RP (Skinner et al., 1991; Crawford et al., 2005; Mordak, 2009), which is consistent with what we saw in our study (Figure 3a). In our study, OD cows tended to have lower haptoglobin concentrations during the last week precalving than $\mathrm{H}$ cows (Table 2). To our knowledge, an association between prepartal haptoglobin concentrations and subsequent RP diagnosis has not been reported. Huzzey et al. (2011) reported that cows with $>1$ disorder or death tended to have higher haptoglobin concentrations during the last 2 wk precalving than cows that remained $\mathrm{H}$, suggesting that prepartal haptoglobin may serve as an indicator of subclinical health problems. In support, we previously showed that persistent, elevated haptoglobin concentrations during the first week postcalving are positively associated with incidence and severity of diseases during early lactation and that elevated haptoglobin concentrations precede clinical disease onset (Sabedra et al., 2012).

Serum concentrations of glucose and urea $\mathrm{N}$ were increased at calving and the first days thereafter for all groups, with greater concentrations observed in RP and OD cows compared with H cows (Figures 3b, 3c). Especially striking was the change in glucose concentrations from being lower in the last week prepartum to being greater in the first $24 \mathrm{~h}$ after calving between $\mathrm{RP}$ and $\mathrm{H}$ cows (Table 2). Elevated concentrations of glucose and urea $\mathrm{N}$ and decreased concentrations of $\alpha$-tocopherol in blood have been reported in the first phase of the acute phase response to LPS (Waldron et al., 2005; Silanikove et al., 2011; Vernay et al., 2012). As haptoglobin responses to bacterial infections are time delayed by approximately $24 \mathrm{~h}$ (Jacobsen et al., 2004) and the increase in serum haptoglobin concentrations during the first week postpartum was greater in RP and OD cows than in $\mathrm{H}$ cows (Figure 3a), higher serum glucose and urea $\mathrm{N}$ concentrations on the first days after calving may be associated with immune responses to infections.

We were interested in serum macromineral concentrations as potential indicators of RP, OD, or both. Some studies reported lower plasma calcium concentrations in the last week precalving in cows with RP compared with those without RP (Chassagne and Chacornac, 1994; Zhang et al., 2002), whereas other studies did not observe group differences for serum or plasma calcium (Kudláč et al., 1995; Quiroz-Rocha et al., 2009), magnesium, or phosphorus concentrations (Kudláč et al., 1995). Hypocalcemia, indicated by serum calcium concentrations $<8 \mathrm{mg} / \mathrm{dL}$, has been proposed as a risk factor for RP as well as OD in early lactation, as intracellular calcium plays an important role in cell signaling (Mulligan et al., 2006; Goff, 2008). In our study, serum calcium concentrations decreased during the last week precalving in all groups but no group differences were observed (Figure 4a).

Serum magnesium concentrations were lower in RP and OD cows during the last week prepartum (Table 2). Magnesium plays an important role in muscle and 
nerve function and its concentrations are tightly controlled in blood (as reviewed by Goff, 2008). Hypomagnesemia, indicated by serum magnesium concentrations $<1.8 \mathrm{mg} / \mathrm{dL}$, is thought to decrease rumen and gastrointestinal tract motility (Goff, 2008). Except around calving, magnesium concentrations in blood usually reflect dietary magnesium intake, as magnesium is well absorbed (Goff, 2000). Thus, lower serum magnesium concentrations during the last week prepartum in RP and OD cows compared with $\mathrm{H}$ cows may reflect lower feed intake. In support, NEFA and BHBA concentrations were higher and serum glucose concentrations were lower during the last week prepartum in RP and OD cows versus $\mathrm{H}$ cows (Table 2).

During 3 to 2 wk prepartum, serum phosphorus concentrations were lower in $\mathrm{RP}$ versus $\mathrm{OD}$ or $\mathrm{H}$ cows (Table 2), suggesting serum phosphorus concentrations at 3 to 2 wk precalving as a risk indicator for RP. Phosphorus is integral to many physiological functions (e.g., ATP, phospholipids, nucleic acids). One challenge of using serum phosphorus concentration as a marker of RP is its wide reference ranges. Normal concentrations of phosphorus vary between 4 and $8 \mathrm{mg} / \mathrm{dL}$ in plasma and usually reflect dietary intake (Goff, 2000). Thus, lower serum phosphorus concentrations in RP compared with $\mathrm{OD}$ or $\mathrm{H}$ cows 3 to $2 \mathrm{wk}$ prepartum may reflect lower feed intake. In support, BCS were lower (Figure 2c) and serum BHBA concentrations were higher in RP versus $\mathrm{OD}$ or $\mathrm{H}$ cows at 3 to $2 \mathrm{wk}$ precalving (Table 2). Serum NEFA and glucose concentrations, however, did not follow similar trends (Table 2).

One objective of this study was to determine if changes in BCS and serum concentrations remain after treatment of RP and for how long they persist. Serum concentrations of $\alpha$-tocopherol and cholesterol remained lower in $\mathrm{RP}$ and $\mathrm{OD}$ compared with $\mathrm{H}$ cows for most of the remaining postpartal sampling period (Figure 1). Group differences were significant if we averaged values for wk 2 to 4 postpartum and wk 5 to 7 postpartum (results not shown). Blood cholesterol, which, together with $\alpha$-tocopherol, is primarily in the high density lipoprotein fraction (approximately $80 \%$ of total cholesterol), is considered an indicator of lipoprotein concentrations and lipid transport, and it decreases with $\alpha$-tocopherol around calving (Herdt and Smith, 1996). Fat feeding and feed restriction increase cholesterol concentrations, reflecting increased lipid transport (Weiss and Wyatt, 2003; Bjerre-Harpøth et al., 2012), whereas heat stress and inflammation-associated diseases (in particular, liver disorders) decrease cholesterol by impeding cholesterol efflux from cells (Abeni et al., 2007; Vogel et al., 2011).

Besides cholesterol concentrations, urea N concentrations were lower in RP and OD cows compared with
$\mathrm{H}$ cows during most of the postpartal sampling period starting at d 14 postpartum (Figure 3c). Cows in RP and OD had lower urea $\mathrm{N}$ concentrations than $\mathrm{H}$ cows for wk 2 to 4 and wk 5 to 7 postpartum (results not shown), suggesting a lower nitrogen balance in RP and OD cows. Given the lower serum cholesterol and urea $\mathrm{N}$ concentrations in RP and OD cows compared with $\mathrm{H}$ cows after the first week postcalving, one would expect similar trends for the 3 serum indicators of energy balance (i.e., NEFA, BHBA, and glucose). However, postpartal serum NEFA, BHBA, and glucose concentrations were either not significantly different between groups or were higher (NEFA and glucose during first $14 \mathrm{~d}$ postpartum) in RP compared with $\mathrm{H}$ cows (Figures $2 \mathrm{a}, 2 \mathrm{~b}$, $3 \mathrm{~b}$ ). If one takes into account BCS and BCS changes, with RP and OD cows generally having lower BCS and losing more BCS after calving than $\mathrm{H}$ cows (Figure 2c), our findings suggest a disconnect between energy and nitrogen balance, with RP and OD cows mobilizing more body protein during early lactation than $\mathrm{H}$ cows.

Another interesting trend in the postpartal period was observed for serum calcium and magnesium concentrations (Figures 4a, 4b). Serum calcium concentrations remained low for longer after calving in RP compared with $\mathrm{H}$ cows (Figure 4a), suggesting delayed calcium homeorhesis in RP cows. Magnesium plays an important role in maintaining calcium homeostasis during early lactation (Goff, 2008). Serum magnesium concentrations below $2 \mathrm{mg} / \mathrm{dL}$, as we observed on average for RP cows at d 7 postpartum (Figure 4b), are thought to contribute to hypocalcemia and suggest insufficient dietary magnesium absorption (Goff, 2000). Given that hypocalcemia decreases DMI and immune function (Goff, 2008), the extended hypocalcemic status of RP cows may increase the risk of OD. In support, RP is an established risk for metritis and ketosis (Curtis et al., 1985; Markusfeld, 1987).

\section{CONCLUSIONS}

To identify risk indicators of RP, OD, or both, in early lactation, we compared peripartal (3 wk before to $7 \mathrm{wk}$ after calving) BCS and serum concentrations of $\alpha$-tocopherol, metabolites (i.e., NEFA, BHBA, cholesterol. glucose, and urea N), haptoglobin, and macrominerals (i.e., calcium, magnesium, and phosphorus) between multiparous dairy cows that developed RP, $\mathrm{OD}$, or remained $\mathrm{H}$ during early lactation. The best early risk indicator for RP was lower prepartal BCS. The best predictive indicators for disease were lower serum $\alpha$-tocopherol concentrations and higher NEFA and BHBA concentrations during the prepartal period. A lower $\alpha$-tocopherol status, lower energy balance (as indicated by higher NEFA, BHBA, and lower glucose 
concentrations), and an inflammatory response preceded or tended to precede clinical onset of RP and OD during the last $3 \mathrm{wk}$ prepartum. Future studies are warranted to validate the potential early predictive indicators and to examine the causal factors, including feed intake, that alter energy balance, acute phase response, and $\alpha$-tocopherol status during the last $3 \mathrm{wk}$ before calving.

\section{ACKNOWLEDGMENTS}

This study was financially supported by the Linus Pauling Institute, Oregon State University (Corvallis), the Oregon State University Agricultural Research Foundation, the Oregon Beef Council (Portland), the Eckelman graduate student scholarship, and a grant from Diamond V (Cedar Rapids, IA). The authors acknowledge the owners and staff of VanBeek Dairy for use of their animals; S. Bledsoe, B. Block, B. Bronson, M. Keller, M. McGuire, P. Ramsing, A. Rudolph, D. Sabedra, C. Sause, C. Shriver-Munsch, M. Swearingen, and E. Zaworski (all in Department of Animal and Rangeland Sciences, Oregon State University, Corvallis) for their assistance with sample collection and data entry; and S. W. Leonard (Linus Pauling Institute, Oregon State University, Corvallis) for technical assistance with vitamin $\mathrm{E}$ analysis.

\section{REFERENCES}

Abeni, F., L. Calamari, and L. Stefanini. 2007. Metabolic conditions of lactating Friesian cows during the hot season in the Po valley. 1. Blood indicators of heat stress. Int. J. Biometeorol. 52:87-96.

Ametaj, B. N., A. Hosseini, J. F. Odhiambo, S. Iqbal, S. Sharma, Q. Deng, T. H. Lam, U. Farooq, Q. Zebeli, and S. M. Dunn. 2011. Application of acute phase proteins for monitoring inflammatory states in cattle. Chapter 13 in Acute Phase Proteins as Early NonSpecific Biomarkers of Human and Veterinary Diseases. F. Veas, ed. InTech, Rijeka, Croatia. Accessed Oct. 24, 2013. http://www. intechopen.com/articles/show/title/application-of-acute-phaseproteins-for-monitoring-inflammatory-states-in-cattle.

Bjerre-Harpøth, V., N. C. Friggens, V. M. Thorup, T. Larsen, B. M. Damgaard, and K. L. Ingvartsen. 2012. Metabolic and production profiles of dairy cows in response to decreased nutrient density to increase physiological imbalance at different stages of lactation. J. Dairy Sci. 95:2362-2380.

Chapinal, N., M. Carson, T. F. Duffield, M. Capel, S. Godden, M. Overton, J. E. P. Santos, and S. J. LeBlanc. 2011. The association of serum metabolites with clinical disease during the transition period. J. Dairy Sci. 94:4897-4903.

Chassagne, M., and J. P. Chacornac. 1994. Blood metabolites as indicators of nutritional risk factors for retained placenta in the dairy cow. Vet. Res. 25:191-195.

Crawford, R. G., K. E. Leslie, R. Bagg, C. P. Dick, and T. F. Duffield. 2005. The impact of controlled release capsules of monensin on postcalving haptoglobin concentrations in dairy cattle. Can. J. Vet. Res. 69:208-214.

Cray, C., J. Zaias, and N. H. Altman. 2009. Acute phase response in animals: A review. Comp. Med. 59:517-526.

Curtis, C. R., H. N. Erb, C. J. Sniffen, R. D. Smith, and D. S. Kronfeld. 1985. Path analysis of dry period nutrition, postpartum met- abolic and reproductive disorders, and mastitis in Holstein cows J. Dairy Sci. 68:2347-2360.

Drillich, M. 2011. Aetiology and therapy of retained fetal membranes in cattle an overview on recent literature. Vet. Med. Austria 98:195-202

Edmonson, A. J., I. J. Lean, L. D. Weaver, T. Farver, and G. Webster 1989. A body condition scoring chart for Holstein dairy cows. J. Dairy Sci. 72:68-78.

Goff, J. P. 2000. Pathophysiology of calcium and phosphorus disorders. Vet. Clin. North Am. Food Anim. Pract. 16:319-337.

Goff, J. P. 2008. The monitoring, prevention, and treatment of milk fever and subclinical hypocalcemia in dairy cows. Vet. J. 176:50-57.

Herdt, T. H., and J. C. Smith. 1996. Blood-lipid and lactation stage factors affecting serum vitamin $\mathrm{E}$ concentrations and vitamin $\mathrm{E}$ cholesterol ratios in dairy cattle. J. Vet. Diagn. Invest. 8:228-232.

Huzzey, J. M., T. F. Duffield, S. J. LeBlanc, D. M. Veira, D. M. Weary and M. A. G. von Keyserlingk. 2009. Short communication: Haptoglobin as an early indicator of metritis. J. Dairy Sci. 92:621-625.

Huzzey, J. M., D. V. Nydam, R. J. Grant, and T. R. Overton. 2011. Associations of prepartum plasma cortisol, haptoglobin, fecal cortisol metabolites, and nonesterified fatty acids with postpartum health status in Holstein dairy cows. J. Dairy Sci. 94:5878-5889.

Jacobsen, S., P. H. Andersen, T. Toelboell, and P. M. H. Heegaard 2004. Dose dependency and individual variability of the lipopolysaccharide induced bovine acute phase protein response. J. Dairy Sci. $87: 3330-3339$

Kaneene, J. B., R. Miller, T. H. Herdt, and J. C. Gardiner. 1997. The association of serum nonesterified fatty acids and cholesterol, management and feeding practices with peripartum disease in dairy cows. Prev. Vet. Med. 31:59-72.

Kelton, D. F., K. D. Lissemore, and R. E. Martin. 1998. Recommendations for recording and calculating the incidence of selected clinical diseases of dairy cattle. J. Dairy Sci. 81:2502-2509.

Kudláč, E., M. Sakour, and J. Cănderle. 1995. Metabolic profile in the peripartal period in cows with afterbirth retention and without it Vet. Med. Czech. 40:201-207.

Laven, R. A., and A. R. Peters. 1996. Bovine retained placenta: Aetiology, pathogenesis and economic loss. Vet. Rec. 139:465-471.

LeBlanc, S. J., T. F. Duffield, K. E. Leslie, K. G. Bateman, J. TenHag, J. S. Walton, and W. H. Johnson. 2002. The effect of prepartum injection of vitamin $\mathrm{E}$ on health in transition dairy cows. J. Dairy Sci. 85:1416-1426

LeBlanc, S. J., T. H. Herdt, W. M. Seymour, T. F. Duffield, and K. E. Leslie. 2004. Prepartum serum vitamin E, retinol, and betacarotene in dairy cattle, and their association with disease. J. Dairy Sci. 87:609-619.

Markusfeld, O. 1987. Periparturient traits in seven high dairy herds, incidence rates, association with parity, and interrelationships among traits. J. Dairy Sci. 70:158-166.

McNaughton, A. P., and R. D. Murray. 2009. Structure and function of the bovine fetomaternal unit in relation to the causes of retained fetal membranes. Vet. Rec. 165:615-622.

Mordak, R. 2009. Postpartum serum concentration of haptoglobin in cows with fetal membranes retention. Cattle Pract. 17:100-102.

Moyes, K. M., T. Larsen, and K. L. Ingvartsen. 2013. Generation of an index for physiological imbalance and its use as a predictor of primary disease in dairy cows during early lactation. J. Dairy Sci. 96:2161-2170

Mulligan, F., L. O'Grady, D. Rice, and M. Doherty. 2006. Production diseases of the transition cows: Milk fever and subclinical hypocalcaemia. Ir. Vet. J. 59:697-701.

NRC. 2001. Nutrient Requirements of Dairy Cattle. 7th rev. ed. Natl. Acad. Sci., Washington, DC.

Ospina, P. A., D. V. Nydam, T. Stokol, and T. R. Overton. 2010. Evaluation of nonesterified fatty acids and $\beta$-hydroxybutyrate in transition dairy cattle in the northeastern United States: Critical thresholds for prediction of clinical diseases. J. Dairy Sci. 93:546-554.

Qu, Y., N. A. Fadden, M. G. Traber, and G. Bobe. 2013a. Depleted serum vitamin $\mathrm{E}$ concentrations precede milk fever in multiparous dairy cows. J. Dairy Sci. 96(E-Suppl. 1):479. (Abstr.) 
Qu, Y., K. Lytle, M. G. Traber, and G. Bobe. 2013b. Depleted serum vitamin $\mathrm{E}$ concentrations precede left displaced abomasum in early lactation dairy cows. J. Dairy Sci. 96:3012-3022.

Quiroz-Rocha, G. F., S. LeBlanc, T. Duffield, D. Wood, K. E. Lesile, and R. M. Jacobs. 2009. Evaluation of prepartum serum cholesterol and fatty acids concentrations as predictors of postpartum retention of the placenta in dairy cows. J. Am. Vet. Med. Assoc. 234:790-793.

Sabedra, D., E. M. Ramsing, C. M. Shriver-Munsch, J. R. Males, W. K. Sanchez, I. Yoon, and G. Bobe. 2012. Haptoglobin is a potential early indicator of postpartal diseases. J. Dairy Sci. 95(Suppl. 2):513. (Abstr.)

SAS Institute. 2009. SAS User's Guide: Statistics. Version 9.2. SAS Inst. Inc., Cary, NC.

Seifi, H. A., S. J. LeBlanc, K. E. Leslie, and T. F. Duffield. 2011. Metabolic predictors of post-partum disease and culling risk in dairy cattle. Vet. J. 188:216-220.

Silanikove, N., A. Rauch-Cohen, F. Shapiro, S. Blum, A. Arieli, and G. Leitner. 2011. Lipopolysaccharide challenge of the mammary gland in bovine induced a transient glandular shift to anaerobic metabolism. J. Dairy Sci. 94:4468-4475.

Skinner, J., R. Brown, and L. Roberts. 1991. Bovine haptoglobin response in clinically defined field conditions. Vet. Rec. 128:147149.

Traber, M. G., and I. Jialal. 2000. Measurement of lipid-soluble vitamins further adjustment needed? Lancet 355:2013-2014.

USDA. 2009. Dairy 2007, Part I: Reference of Dairy Cattle Health and Management Practices in the United States, 2007. USDA-Animal and Plant Health Inspection Service (APHIS)-Veterinary Services (VS), Center for Epidemiology and Animal Health (CEAH), Fort Collins, CO.

Vernay, M. C. M. B., O. Wellnitz, L. Kreipe, H. A. van Dorland, and R. M. Bruckmaier. 2012. Local and systemic response to intramammary lipopolysaccharide challenge during long-term manipulated plasma glucose and insulin concentrations in dairy cows. J. Dairy Sci. 95:2540-2549.

Vogel, K. D., J. R. Claus, T. Grandin, G. R. Oetzel, and D. M. Schaefer. 2011. Effect of water and feed withdrawal and health status on blood and serum components, body weight loss, and meat and carcass characteristics of Holstein slaughter cows. J. Anim. Sci. 89:538-548.

Waldron, M. R., B. J. Nonnecke, R. L. Horst, A. E. Kulick, and T. R. Overton. 2005. Acute experimental mastitis perturbs plasma macromineral and $\alpha$-tocopherol concentrations in early-lactation dairy cows. J. Dairy Sci. 88(Suppl. 1):198. (Abstr.)

Weiss, W. P. 1998. Requirement of fat-soluble vitamins for dairy cows: A review. J. Dairy Sci. 81:2493-2501.

Weiss, W. P., and D. J. Wyatt. 2003. Effect of dietary fat and vitamin $\mathrm{E}$ on $\alpha$-tocopherol in milk from dairy cows. J. Dairy Sci. 86:3582-3591.

Zhang, W. C., T. Nakao, K. Kida, M. Moriyoshi, and K. Nakada. 2002. Effect of nutrition during pregnancy on calf birth weights and viability and fetal membrane expulsion in cattle. J. Reprod. Dev. 48:415-422. 